\title{
SEBARAN SITUS PEMUKIMAN KUNA DI DAERAH ALIRAN SUNGAI BARITO
}

\author{
Sunarningsih* \\ BalaiArkeologi Banjarmasin, Jalan Gotong Royong II, RT 03/06, Banjarbaru 70711, Kalimantan Selatan; \\ Telepon (0511) 4781716; Facsimile (0511) 4781716
}

Artikel masuk pada 3 Maret 2012

Artikel selesai disunting pada 23 September 2012

\begin{abstract}
Abstrak. Sungai Barito dan anak-anak sungainya yang berada di wilayah Provinsi Kalimantan Selatan mengandung banyak situs pemukiman dari masa yang berbeda. Situs-situs pemukiman prasejarah, baik tertutup (gua) maupun terbuka (tepian sungai), yang telah diteliti ditemukan di kawasan lereng barat Pegunungan Meratus, yang masuk dalam wilayah administratif Kabupaten Hulu Sungai Utara, Kabupaten Hulu Sungai Tengah, Kabupaten Hulu Sungai Selatan, Kabupaten Tapin, dan Kabupaten Barito Kuala. Namun, ternyata hasil analisis artefaktual dan pertanggalan mutlak menunjukkan bahwa sejumlah situs pemukiman terbuka masa prasejarah dapat dikategorikan juga sebagai situs proto-histori dan masa pengaruh kebudayaan India. Situs-situs pemukiman dengan karakteristik periodisasi beragam menggambarkan bahwa terdapat kontinuitas dalam konsep pemilihan lokasi hunian yang sama. Berdasarkan hal tersebut, tulisan ini membahas pola persebaran situs-situs pemukiman kuna tersebut. Hasil studi pemukiman terbuka ini menunjukkan bahwa pola persebaran situs pada Sungai Barito cenderung linear sejajar dengan badan sungai.
\end{abstract}

Kata kunci: pemukiman tertutup, pemukiman terbuka, daerah aliran sungai, pola linear, gerabah, keramik asing, arang, fabric analysis

Abstract. ARCHAEOLOGICAL SETTLEMENT SITE DISTRIBUTION ON THE BARITO RIVER BASIN. The Barito River and its tributaries which are located in South Kalimantan region contains many settlement sites dated from different periods. Prehistoric settlement sites, either closed (cave) or open (banks), which have been studied are found in the western slopes of the Meratus Mountain, are located in the administrative regions of Hulu Sungai Utara District, Hulu Sungai Tengah District, Hulu Sungai Selatan District, Tapin District and Barito Kuala District. However, apparently, results from artefact and absolute dating analysis indicate that some prehistoric opensettlement sites can be categorized as well as sites from the proto-historic period and the period of Indic-cultureinfluence. Settlement sites with multi-dated characteristic suggest continuity in the concept of selecting the same dwelling location. Therefore, this paper discusses the distribution patterns of these settlement sites. The results shows that the site distribution pattern on the Barito River tends to stretch linearly parallel to the water bodies.

Keywords: close-settlement, open-settlement, river basin, linear pattern, pottery, ceramics, charcoal, fabric analysis

* Penulis adalah Peneliti Madya pada Balai Arkeologi Banjarmasin, email: asihwasita@yahoo.com 


\section{A. Pendahuluan}

Sungai Barito merupakan sungai besar yang mengalir di dua wilayah provinsi di Kalimantan, yaitu Provinsi Kalimantan Selatan dan Provinsi Kalimantan Tengah. Dengan kata lain, Sungai Barito merupakan induk sungai di Kalimantan Selatan dan Kalimantan Tengah. Muara dari sungai ini adalah Laut Jawa, sedangkan hulu dari sungai ini adalah Pegunungan Muller. Selain bersumber di Pegunungan Muller, ternyata sungai ini juga mendapat aliran air dari Pegunungan Meratus yang letaknya lebih ke arah hilir. Berikut adalah uraian tentang anak Sungai Barito ${ }^{1}$. Anak Sungai Barito di daerah hulu (termasuk wilayah Provinsi Kalimantan Tengah), tepatnya di wilayah Kabupaten Murung Raya antara lain adalah Sungai Laung, Sungai Babuat, Sungai Joloi, dan Sungai Busang. Anak Sungai Barito yang mengalir di wilayah Kabupaten Barito Utara, antara lain adalah Sungai Montalat, Sungai Teweh, dan Sungai Lahei. Di Kabupaten Barito Selatan terdapat 11 anak Sungai Barito. yaitu Sungai Jenamas, Sungai Kelanis/Napu, Sungai Mangkatip, Sungai Karau/Bangkuang, Sungai Puning, Sungai Ayuh, Sungai Bamanen/Bundar, Sungai Tabuk/Buntok Kota, Sungai Telang, Sungai Janggi, dan Sungai Bahaur. Selanjutnya, anak Sungai Barito juga mengalir di wilayah Provinsi Kalimantan Selatan. Sungai Paminggir mengalir di wilayah Kabupaten Hulu Sungai Utara. Di wilayah Kabupaten Barito Kuala terdapat Sungai Ulak, Sungai Seluang, Sungai Belawang, Sungai Pelingkau, Sungai Sabrang, dan Sungai Belandean. Di Kabupaten Barito Kuala juga terdapat cabang Sungai Barito, yakni Sungai Kapuas Murung yang menghubungkan wilayah Kabupaten Kuala Kapuas, Kalimantan Tengah. Selain itu, Sungai Barito ke arah hilir juga memiliki dua anak sungai yang besar, yaitu Sungai Bahan atau Nagara dan Sungai Martapura. Sungai Nagara memiliki beberapa cabang sungai, yakni Tabalong, Balangan, Pitap, Alai, Amandit, dan Amas. Sungai-sungai tersebut berhulu di Pegunungan Meratus. Adapun Sungai Martapura melewati Kota Banjarmasin dan Martapura, yang juga berhulu di Pegunungan Meratus.

Keberadaan Sungai Barito dan anak sungainya tampaknya telah memberi banyak pengaruh terhadap kehidupan masyarakat yang hidup di sekitarnya, dari dulu hingga sekarang. Hal tersebut antara lain dapat dilihat dari hasil penelitian arkeologi yang telah dilakukan oleh Balai Arkeologi Banjarmasin di beberapa situs pemukiman di sepanjang Daerah Aliran Sungai Barito. Pengumpulan data yang digunakan dalam penelitian terhadap beberapa pemukiman kuna tersebut menggunakan metode survei, ekskavasi, dan wawancara. Analisis yang sudah dilakukan antara lain analisis khusus (spesific analysis) terhadap fragmen gerabah, fragmen keramik asing, alat kayu, dan manik-manik, serta analisis laboratorium dengan melakukan carbon dating pada sampel arang dan kayu. Memang belum semua daerah aliran sungai ini telah diteliti, tetapi dari beberapa penelitian sudah tampak sedikit gambaran tentang pemukiman masyarakat masa lalu yang berasal dari masa proto histori ke masa yang lebih muda. Keberadaan situs pemukiman tersebut selanjutnya akan coba didiskusikan persebarannya, dengan melihat kembali aliran sungai yang telah menjadi hunian dari masa lalu. Hasilnya diharapkan dapat

\footnotetext{
1 Http://id.wikibook.org/wiki/pelayaran_Sungai_dan_Danau/Perairan_Daratan_yang_Bisa_Dilayari\#Sungai_Barito
} 
dijadikan bahan pertimbangan untuk melakukan penelitian lanjutan.

\section{B. Situs Pemukiman Kuna di Daerah Aliran Sungai Barito}

Sejak berdirinya Balai Arkeologi Banjarmasin (1996) hingga sekarang, telah dilakukan beberapa penelitian di DAS Barito. Penelitian arkeologi dilakukan baik dengan survei maupun ekskavasi. Berdasarkan data yang ada, tampak bahwa daerah hulu Sungai Barito masih relatif kurang jumlah penelitiannya dibandingkan dengan daerah hilir Sungai Barito. Daerah hilir tersebut adalah di sepanjang anak Sungai Barito yang mengalir di wilayah Provinsi Kalimantan Selatan, yaitu Sungai Bahan (Nagara) dan Sungai Martapura. Aliran Sungai Nagara lebih panjang dibandingkan Sungai Martapura. Sungai Nagara juga memiliki anak sungai yang lebih banyak dibandingkan Sungai Martapura. Hal yang menarik adalah keberadaan pemukiman kuna yang lebih tua berada di sepanjang Sungai Nagara, yaitu dari masa proto sejarah dan masa pengaruh Hindu Budha. Di sisi lain, Sungai Martapura menjadi sangat berperan pada masa pengaruh Islam. Kerajaan Banjar pada masa kejayaannya membangun pusat kerajaannya di sepanjang Sungai Martapura.

Selanjutnya akan diuraikan keberadaan situs pemukiman kuna di sepanjang aliran Sungai Nagara yang antara lain melewati wilayah Kabupaten Barito Kuala, Kabupaten Tapin, Kabupaten Hulu Sungai Selatan, Kabupaten Hulu Sungai Tengah, Kabupaten Hulu Sungai Utara, dan Kabupaten Tanjung. Uraian situs pemukiman kuna akan dimulai dari wilayah kabupaten yang yang berada di hilir atau tepatnya di muara Sungai Nagara (Sungai Barito), yaitu Kabupaten Barito Kuala dan dilanjutkan ke wilayah kabupaten lain ke arah hulu di Kabupaten Tabalong.

\section{Situs Pemukiman Kuna di Kabupaten Barito Kuala}

Kabupaten Barito Kuala yang terletak di muara Sungai Barito beribukota di Marabahan. Di wilayah Kabupaten Barito Kuala terdapat tiga buah situs pemukiman kuna, dua di antaranya terletak di Desa Jajangkit, Kecamatan Mandastana dan Sungai Talaran Km 2, Kelurahan Ulu Benteng, Kecamatan Bakumpai. Di kedua situs tersebut terdapat manik yang ditemukan oleh penduduk setempat pada saat aktivitas mendulang berlangsung. Manik tersebut terdiri atas manik batu, tembikar, dan kaca. Jenis manik batu disebut sebagai lamiang yang berbahan batu karnelian, sedangkan manik artifisialnya antara lain berupa manik tembikar yang dibuat dari tanah liat bakar, manik kaca Indo-Pasifik, manik kaca mozaik, dan manik lain dari beragam warna dan bentuk baik monokrom maupun polikrom. (Atmojo 1998/99; Triatno, dkk. 1998/99).

Situs lainnya berada di Desa Patih Muhur, Kecamatan Anjir Muara, tepatnya di tepi Sungai Barito. Situs ini banyak mendapat perhatian dari media masa, baik lokal maupun nasional. Kegiatan survei tehadap situs ini menghasilkan informasi penduduk tentang temuan artefaktual berupa kapak, beliung, dayung, perhiasan (cincin emas), dan kowi. Luas situs diperkirakan mencapai 0,5 hektar. Dari hasil pengamatan dapat dilihat adanya sebaran 20 tonggak kayu ulin yang tampak di permukaan tanah setinggi $40 \mathrm{~cm}$, dengan ukuran diameter yang beragam. Di sekitar tonggak tersebut ditemukan juga fragmen keramik asing. Selanjutnya, kegiatan ekskavasi dilakukan dan diketahui bahwa gelondongan kayu ulin yang ditanam dan 
membentuk pola tertentu ternyata disusun dengan menggunakan konstruksi kalang sunduk ${ }^{2}$. Berdasarkan hasil carbon dating dari sampel kayunya berasal dari abad ke-14 Masehi (Wasita 2007).

\section{Situs Pemukiman Kuna di Kabupaten Tapin}

Kabupaten Tapin yang beribukota di Rantau juga memiliki beberapa situs pemukiman kuna. Di wilayah ini terdapat situs pemukiman masa prasejarah, yaitu Situs Banua Hanyar. Keberadaan situs ini diketahui berdasarkan penelitian kerjasama antara Pemerintah Kabupaten Tapin yang diwakili oleh Dinas Kebudayaan dan Pariwisata Kabupaten Tapin, dengan Balai Arkeologi Banjarmasin dalam penelitian di Masjid Banua Halat. Dari hasil ekskavasi yang dilakukan di halaman masjid, ditemukan fragmen gerabah dan sisa-sisa tiang. Selanjutnya, sisa tiang tersebut dianalisis dan didapatkan umur 5302 dan 5630 BC (Tim Peneliti Arkeologi 2006). Dengan demikian dapat disimpulkan bahwa pemukiman di halaman masjid tersebut berasal dari masa prasejarah dan pemukiman di lokasi tersebut berkelanjutan hingga masa yang selanjutnya.

Situs lainnya yang sangat menarik di kabupaten ini adalah Situs Candi Laras dan Situs Pematang Bata, yang berada di Kecamatan Candi Laras Selatan. Keduanya berada di persimpangan Sungai Nagara dan Sungai Tapin. Kedua situs telah diteliti oleh Balai Arkeologi Banjarmasin dengan melakukan ekskavasi dan analisis pertanggalan secara absolut. Kondisi Situs Candi Laras hanya meninggalkan sebuah telaga yang ramai dikunjungi masyarakat untuk mendapat berkah. Tidak sesuai dengan namanya yaitu candi, keberadaan batubata di tempat tersebut sudah hancur bercampur dengan tanah. Tidak demikian halnya dengan Situs Pematang Bata, sisa bata di tempat tersebut masih ditemukan, tetapi bentuk bangunannya sudah tidak dapat diketahui lagi karena aktivitas penggalian liar yang sudah berlangsung lama. Dari hasil ekskavasi dapat diketahui bahwa di Candi Laras terdapat sebuah bangunan kayu yang juga menggunakan konstruksi kalang sunduk. Selanjutnya, berdasarkan hasil pertanggalan absolut dengan menggunakan analisis radiocarbon dari sampel kayu ulin dari Situs Candi Laras, menghasilkan angka tahun sekitar awal abad ke-11 sampai abad ke -13 Masehi (Sulistyanto 2000).

\section{Situs Pemukiman Kuna di Kabupaten Hulu Sungai Selatan}

Kabupaten Hulu Sungai Selatan dengan ibukotanya di Kandangan dialiri oleh Sungai Amandit yang pada akhirnya bermuara di Sungai Nagara. Di wilayah Kabupaten Hulu Sungai Selatan ada beberapa situs pemukiman yang sudah diteliti oleh Balai Arkeologi Banjarmasin baik dengan metode survei ataupun ekskavasi. Situs tersebut adalah Situs Jambu Hulu, Jambu Hilir, dan situs-situs di Nagara. Situs Jambu Hilir dan Situs Jambu Hulu terletak di daerah aliran Sungai Amandit. Keduanya memiliki kesamaan temuan, yaitu fragmen keramik bercampur dengan fragmen gerabah di permukaan tanah. Kondisi Situs Jambu Hulu sudah sangat teraduk oleh penggalian

\footnotetext{
2 kalang=penahan, sunduk=kunci. Kalang sunduk dipakai sebagai konstruksi rumah panggung guna memperkokoh bagian dasar bangunan yang berada di atas tanah rawa yang kurang stabil.
} 
penduduk yang sudah berlangsung cukup lama. Mereka banyak menemukan benda berharga yang terbuat dari logam emas di areal situs tersebut. Letak Situs Jambu Hilir tidak tepat berada di tepi Sungai Amandit, tetapi di anak sungainya yang saat ini sudah tidak mengalir lagi, yaitu Sungai Rangas. Meskipun aliran Sungai Rangas sudah mati, pada saat musim hujan masih tergenang oleh air dan pada sebagian aliran terutama yang berada di arah hilir masih digunakan oleh penduduk sebagai tempat mandi dan cuci. Sedangkan Situs Jambu Hulu yang berada di arah hulu berada tepat di tepi Sungai Amandit. Seperti halnya Situs Jambu Hilir, pada permukaan tanah banyak terdapat fragmen keramik bercampur dengan fragmen gerabah. Berdasarkan hasil analisis radiocarbon dating yang berasal dari sampel arang di kedua situs tersebut didapatkan angka tahun yang sangat jauh berbeda, yaitu 1000 SM (Jambu Hilir), dan 1000 M (Jambu Hulu) (Anggraeni dan Sunarningsih 2008). Meskipun demikian, apabila dilihat dari artefak yang ditemukan tampak adanya persamaan, terutama pada temuan fragmen gerabah (sebagai temuan dominan) yang memiliki kemiripan baik dari segi bentuk, pola hias, cara pembuatan, maupun fabric penyusun gerabah itu sendiri.

Selanjutnya, adalah pemukiman kuna Balanti yang juga berada di aliran Sungai Amandit. Keberadaan sisa pemukiman kuna di Desa Balanti, Kecamatan Kalumpang, Kabupaten Hulu Sungai Selatan diketahui dari informasi penduduk pada saat tim penelitian Balai Arkeologi Banjarmasin melakukan ekskavasi di Situs Jambu Hulu pada tahun 2011. Desa Balanti berjarak sekitar $15 \mathrm{~km}$ dari Kota Kandangan. Berdasarkan informasi tersebut, dilakukan peninjauan disela kegiatan penelitian untuk mengetahui kondisi temuannya. Dari hasil survei dapat diketahui bahwa sebaran hunian masa lampau di wilayah Kalumpang ini juga cukup luas. Sisa hunian tersebut berada di antara dua sungai yang pada saat ini sudah mati. Dari pengamatan terhadap hasil aktivitas salah seorang penduduk yang membuat sumur gali di belakang rumahnya, tampak bahwa temuan pecahan gerabahnya lumayan padat. Tampaknya keberadaan situs pemukiman ini memang terlambat diketahui. Tidak jauh dari desa ini terdapat sebuah desa yang bernama Desa Tembingkar. Masyarakat di sini menyebut tembikar dengan istilah tembingkar. Apakah di desa ini juga banyak ditemukan fragmen tembikar masih perlu dibuktikan dengan melakukan penelitian arkeologi. Temuan serupa juga ada di Pantai Amas, yang masih di wilayah Kabupaten Hulu Sungai Selatan.

Situs pemukiman kuna lainnya yang tidak kalah menarik adalah situs-situs di wilayah Nagara. Daerah ini berada di persimpangan sungai yang dikenal sebagai Tumbukan Banyu, di mana tiga buah aliran sungai bertemu, yaitu ke arah Amuntai, Barabai, dan Margasari. Keberadaan situs pemukiman yang sudah disurvei dan diekskavasi adalah yang ke arah Margasari (Kabupaten Tapin). Di sepanjang aliran Sungai Nagara dari Tumbukan Banyu sampai dengan lokasi Situs Candi Laras, terdapat pemukiman kuna yang berada di kedua sisi sungai. Desa-desa yang mengandung temuan artefak berupa fragmen gerabah, fragmen keramik, manik-manik, sisa kapal dan peralatannya (dayung). Desa yang berada di dekat Tumbukan Banyu adalah Desa Panggandingan dan Tambak Bitin (Sunarningsih 2007). Di Desa Panggandingan (Kecamatan Daha Utara) terdapat sebuah tempat yang lebih tinggi dari 
tempat lainnya di wilayah Nagara. Tempat tersebut pada saat ini difungsikan sebagai kuburan. Di sekitarnya banyak ditemukan fragmen gerabah dan fragmen keramik Cina. Hal yang menarik dari situs pemukiman ini adalah ditemukannya batu bata dan fragmen genteng yang sama dengan batu bata dan genteng dari Situs Candi Agung. Selain itu, masyarakat di sekitar Tumbukan Banyu pada saat ini memiliki profesi sebagai pembuat gerabah, pande besi, dan barang lainnya dari logam seperti baling-baling kapal dan berbagai peralatan dapur. Orang-orang Nagara sebagai pembuat gerabah dan pande besi sangat terkenal, terutama di wilayah Kalimantan Selatan dan Kalimantan Tengah. Hasil karya mereka dipasarkan di wilayah kedua provinsi tersebut. Desa lain yang juga mengandung temuan artefak serupa adalah desa-desa di dua sisi Sungai Nagara ke arah hilir yang menuju ke Desa Margasari (Kabupaten Tapin). Desa-desa tersebut termasuk dalam wilayah Kecamatan Daha Barat, yaitu Siang Gantung, Tanjung Selor, Bajayau, Bajayau Tengah, dan Bajayau Lama (Sunarningsih 2007). Beberapa desa di antaranya sudah disurvei oleh Balai Arkeologi Banjarmasin. Keberadaan artefak di wilayah tersebut diketahui dari adanya aktivitas penduduk yang melakukan penggalian liar dan menemukan banyak benda berharga seperti manik-manik, dan perhiasan emas. Pemukiman kuna di Kecamatan Daha Barat yang berbatasan langsung dengan wilayah Kabupaten Tapin pada saat ini tidak berada tepat di bibir sungai, tetapi berjarak antara 500 meter sampai dengan $1 \mathrm{~km}$ menjauh dari tepi sungai. Meskipun demikian, karena letaknya di daerah pasang surut maka hampir setiap tahun selalu terendam air. Selain itu, berdasarkan informasi penduduk, ada pemukiman kuna lainnya yang berada di sepanjang aliran Batang Banyu Mati. Letak sungai mati tersebut berada di belakang Desa Tanjung Selor yang mengalir sejajar dengan Sungai Nagara. Akan tetapi, aliran Batang Banyu Mati belum disurvei lebih lanjut, sehingga belum diketahui kondisi artefak dan sebaran temuannya.

Masa hunian sisa pemukiman kuna di wilayah Sungai Nagara ini masih belum dapat diketahui secara jelas. Akan tetapi, tampaknya terdapat perbedaan hasil temuan di Kecamatan Daha Barat dan Daha Utara. Fragmen gerabah di wilayah Daha Barat terlihat lebih tebal dan lebih banyak berupa alat dapur, selain itu temuan keramik asing sangat jarang. Artefak yang sering ditemukan penduduk di tempat ini adalah berbagai peralatan dari kayu, seperti dayung, pemberat jala, serta manik-manik dari batu dan kaca. Selain itu, penduduk juga pernah menemukan patung terbuat dari kayu dan logam. Sebaliknya, temuan di Desa Penggandingan (Daha Utara) banyak berupa pecahan genteng dari tanah liat dan keramik asing.

\section{Situs Pemukiman Kuna di Kabupaten Hulu Sungai Tengah}

Kabupaten Hulu Sungai Tengah beribukota di Barabai, yang juga dialiri oleh anak Sungai Nagara. Seperti yang sudah diuraikan di atas bahwa di Tumbukan Banyu tiga aliran sungai bertemu, yaitu ke arah Barabai (Hulu Sungai Tengah), Amuntai (Hulu Sungai Utara), dan Margasari (Tapin). Keberadaan situs pemukiman kuna di Kabupaten Hulu Sungai Tengah belum pernah diteliti. Meskipun demikian, di daerah ini terdapat pengrajin topeng dan juga mempunyai dalang yang biasa memainkan wayang Banjar, yaitu di Barikin. Topeng yang dibuat, biasanya dipakai pada saat pementasan wayang gong, yang mirip dengan 
kesenian wayang orang di Jawa.

\section{Situs Pemukiman Kuna di Kabupaten Hulu Sungai Utara \\ Kabupaten Hulu Sungai Utara beribukota} di Amuntai. Kota Amuntai terletak di daerah rawa dan berada di persimpangan tiga aliran sungai, yaitu Sungai Tabalong, Sungai Balangan, dan Sungai Nagara. Di Amuntai ini pada tahun 1964 dilakukan penelitian terhadap keberadaan sebuah gundukan yang mengandung banyak batubata. Dari hasil pemugaran yang dilakukan sejak tahun 1978 sampai dengan 1982, berdirilah pondasi, bagian bangunan yang bernama Candi Agung. Penelitian terhadap candi dan lingkungannya yang dilaksanakan pada 1994 mendapatkan indikasi adanya pemukiman kuna di sekitar candi. Selanjutnya pada penelitian tahun 1996, diketahui adanya pemukiman dari dua masa yang berbeda, dari masa yang sezaman dengan candi dan masa prasejarah (sebelum pengaruh Hindu-Budha masuk). Berdasarkan hasil analisis radiocarbon dating didapatkan dua angka tahun, yaitu dari sampel kayu ulin yang semasa dengan candi didapatkan angka pertanggalan abad ke-8 Masehi, sedangkan sampel arang yang berasosiasi dengan temuan fragmen gerabah dari lapisan tanah yang lebih dalam (diambil dari kotak ekskavasi tidak jauh dari candi) didapatkan angka abad ke-3 SM. Keberadaan candi ini sering dikaitkan dengan Negara Dipa yang keberadaannya diketahui dari Hikayat Banjar. Keberadaan Negara Dipa tersebut berkaitan dengan Kerajaan Majapahit di Jawa yang mencapai kejayaannya pada abad ke14 Masehi. Oleh karena itu, umur Candi Agung secara relatif bisa dikatakan dari abad ke-14 Masehi, tetapi pertanggalan absolutnya jauh lebih tua yaitu dari abad ke-8 Masehi
(Kusmartono dan Widianto 1997/1998). Selisih angka tahun yang sangat jauh tersebut tentunya menyisakan banyak pertanyaan, data mana yang bisa lebih dipercaya.

\section{Situs Pemukiman Kuna di Kabupaten Tabalong}

Kabupaten Tabalong terletak di paling ujung (atas) wilayah Propinsi Kalimantan Selatan, yang beribukota di Tanjung. Sungai yang membelah Kota Tanjung disebut dengan Sungai Tabalong. Pada saat ini, data pemukiman kuna yang ada di wilayah Tabalong adalah pemukiman di sepanjang Sungai Jangkung. Salah satu tempat yang banyak ditemukan fragmen keramik asing dan fragmen tembikar adalah di sebuah bukit yang dikenal oleh masyarakat sekitar sebagai Pulau Jangkung. Dianggap sebagai pulau karena bukit kecil ini sebagian wilayahnya dikelilingi oleh sebuah sungai yang merupakan anak Sungai Jangkung. Di lokasi pemukiman tersebut banyak ditemukan frgamen keramik asing yang tersebar di permukaan areal kebun pisang. Sungai Jangkung merupakan anak Sungai Tabalong yang mengalir ke beberapa wilayah desa/kelurahan di Kecamatan Tanjung.

\section{Sebaran Situs Pemukiman Kuna}

Belum semua situs pemukiman kuna di atas diketahui masa huniannya (Tabel 1). Meskipun demikian, dari hasil pertanggalan absolut yang sudah ada dan perbandingan artefak yang ditemukan pada masing-masing situs dapat diasumsikan bahwa situs pemukiman yang dianggap berasal dari masa Hindu Budha adalah situs-situs seperti Candi Agung, Candi Laras, dan Pematang Bata, serta Patih Muhur. Selain berasosiasi 
dengan bangunan candi, berdasarkan hasil analisis carbon dating juga menunjukkan bahwa situs tersebut berasal dari masa pengaruh Hindu Budha. Sampel kayu Candi Agung berasal dari abad ke-8 Masehi, sedangkan arang dari Candi Laras berasal dari abad ke-13 Masehi (Kusmartono dan Widianto 1997/1998; Sulistyanto 2000), sedangkan Patih Muhur berasal dari abad ke14 Masehi (Wasita 2007). Namun demikian, tampaknya situs pemukiman lainnya juga dapat dimasukkan ke dalam masa Hindu Budha meskipun tidak berkonteks dengan temuan candi. Temuan di situs pemukiman tersebut biasanya berupa fragmen keramik Cina dari dinasti Song, Yuan atau bahkan dari masa yang lebih muda, yaitu Dinasti Ming dan Qing. Keberadaan keramik Cina tersebut biasanya ditemukan bercampur dengan keramik asing lainnya seperti dari Vietnam, Thailand, dan Eropa. Temuan fragmen keramik asing tersebut biasanya juga berada di permukaan tanah seperti yang terlihat di Situs Jambu Hulu dan Jambu Hilir. Selain di kedua situs tersebut, sebaran keramik juga ditemukan di Situs Panggandingan, Kecamatan Daha Utara, Kabupaten Hulu Sungai Selatan (Sunarningsih 2007). Di situs ini selain banyak fragmen keramik asing juga ditemukan fragmen genteng dan batu bata, seperti yang ditemukan di Situs Candi Agung. Selain itu, di sepanjang Sungai Nagara juga terdapat situs pemukiman masa Hindu Budha, yaitu Situs Panggandingan (Daha Utara), yang didasarkan pada temuan fragmen genteng yang sama dengan yang ditemukan di Candi Agung. Selain itu, pemukiman kuna juga ditemukan tersebar baik di kiri dan kanan sungai yang meliputi beberapa desa antara lain Desa Tanjung Selor, Bajayau, dan Bajayau Lama. Namun, belum diketahui masa hunian dari situs pemukiman tesebut apakah masuk masa klasik atau proto sejarah, atau merupakan situs yang digunakan secara berkelanjutan. Kemungkinan temuan yang sama juga ada di pemukiman kuna sepanjang aliran Batang Banyu Mati. Selain itu, situs pemukiman lain yang juga mengandung temuan fragmen keramik cina dan fragmen gerabah, tetapi belum diteliti lebih lanjut antara lain adalah Situs Jajangkit dan Ulu Benteng (Kabupaten Batola), Situs Balanti dan Pantai Amas (Kabupaten Hulu Sungai Selatan), dan Situs Jangkung (Kabupaten Tabalong). Keberadaan keramik Cina tersebut berasal dari beberapa dinasti yang berbeda (Song, Yuan, Ming, dan Qing), selain keramik dari Vietnam, Thailand, dan Eropa.

Selanjutnya, beberapa situs permukiman di atas ternyata juga memiliki satu lapisan budaya dari masa yang berbeda, yang ditemukan setelah dilakukan ekskavasi dan analisis pertanggalan absolut, baik dengan menggunakan sampel arang maupun sampel kayu. Situs-situs tersebut adalah Situs Candi Agung (300 SM), Situs Jambu Hilir (1000 SM), Situs Jambu Hulu (1000 M), dan Situs Masjid Banua Halat (5000 SM). Angka tahun yang didapatkan di Jambu Hilir sebenarnya bisa dimasukkan dalam masa Hindu Budha, tetapi apabila dibandingkan temuan gerabahnya ternyata tidak jauh berbeda dengan gerabah dari Situs Jambu Hilir.

Dari segi bentuk, banyak ditemukan wadah gerabah baik yang terbuka mapun tertutup (Nasruddin 1996/1997). Wadah terbuka antara lain berbentuk mangkuk, sedangkan wadah tertutupnya memiliki bentuk periuk. Dari kedua jenis wadah tersebut tampaknya lebih banyak memiliki dasar yang tidak rata, yaitu bentuk cincin. Dari pengamatan terhadap jenis artefak ini, banyak dijumpai keberadaan dasar cincin yang sudah 
Tabel 1. Situs Pemukiman Kuna di DAS Barito, Kalimantan Selatan

\begin{tabular}{|c|c|c|c|c|}
\hline No & Nama Situs & Lokasi & Temuan & Periodesasi \\
\hline 1 & Patih Muhur & $\begin{array}{l}\text { Kecamatan Anjir } \\
\text { Muara, Kabupaten } \\
\text { Barito Kuala }\end{array}$ & $\begin{array}{l}\text { Tonggak ulin membentuk konstruksi bangunan, } \\
\text { kapak dan beliung batu, dayung kayu ulin, } \\
\text { perhiasan emas, kowi, fragmen keramik asing, } \\
\text { fragmen gerabah }\end{array}$ & $\begin{array}{l}\text { Abad ke-14 Masehi (car- } \\
\text { bon dating dari sampel } \\
\text { kayu) }\end{array}$ \\
\hline 2 & Jajangkit & $\begin{array}{l}\text { Ke c a m a t a } n \\
\text { Mandastana, } \\
\text { Kabupaten Barito } \\
\text { Kuala }\end{array}$ & Manik (batu dan kaca), fragmen gerabah & Sejarah (?) \\
\hline 3 & Ulu Benteng & $\begin{array}{l}\text { Ke c a m a t a n } \\
\text { B a k u m p a i, } \\
\text { Kabupaten Barito } \\
\text { Kuala }\end{array}$ & Manik (batu dan kaca), fragmen gerabah & Sejarah (?) \\
\hline 4 & Candi Laras & $\begin{array}{l}\text { Kecamatan Candi } \\
\text { Laras, Kabupaten } \\
\text { Tapin }\end{array}$ & $\begin{array}{l}\text { Fragmen batubata, sisa konstruksi bangunan } \\
\text { (rumah) dari kayu }\end{array}$ & $\begin{array}{l}\text { Abad ke-11-13 Masehi } \\
\text { (carbon dating dari sampel } \\
\text { kayu) }\end{array}$ \\
\hline 5 & Banua Hanyar & Kabupaten Tapin & Fragmen gerabah dan sisa tiang bangunan (?) & $\begin{array}{l}5302 \text { dan } 5630 \text { BC (car- } \\
\text { bon dating dari sampel } \\
\text { tiang kayu) }\end{array}$ \\
\hline 6 & Balanti & $\begin{array}{l}\text { Ke c a m a t a n } \\
\text { Kalum pang, } \\
\text { Kabupaten Hulu } \\
\text { Sungai Selatan }\end{array}$ & Fragmen gerabah & $\begin{array}{l}\text { Proto sejarah atau masa } \\
\text { sejarah (?) }\end{array}$ \\
\hline 7 & Jambu Hulu & $\begin{array}{l}\text { Ke c a m a t a } n \\
\text { Padang Batung, } \\
\text { Kabupaten Hulu } \\
\text { Sungai Selatan }\end{array}$ & $\begin{array}{l}\text { Fragmen gerabah, manik tanah liat, fragmen } \\
\text { keramik asing, fragmen perhiasan emas }\end{array}$ & $\begin{array}{l}940 \pm 110 \mathrm{BP}(1000 \mathrm{AD}), \\
\text { carbon dating dari sampel } \\
\text { arang }\end{array}$ \\
\hline 8 & Jambu Hilir & $\begin{array}{l}\text { Ke c a m a t a n } \\
\text { Kand ang a n, } \\
\text { Kabupaten Hulu } \\
\text { Sungai Selatan }\end{array}$ & $\begin{array}{l}\text { Fragmen gerabah, manik tanah liat, fragmen } \\
\text { keramik asing, kowi, terak besi, perhiasan } \\
\text { emas }\end{array}$ & $\begin{array}{l}3000 \mathrm{BP}(1000 \mathrm{BC}) \text {, car- } \\
\text { bon dating dari sampel } \\
\text { arang }\end{array}$ \\
\hline 9 & $\begin{array}{l}\text { Bajayau, dkk } \\
\text { (Siang gantung, } \\
\text { Tanjung Selor, } \\
\text { Bajayau Lama, } \\
\text { Bajayau Tengah) }\end{array}$ & $\begin{array}{l}\text { Kecamatan Daha } \\
\text { Barat, Kabupaten } \\
\text { Hulu Sungai } \\
\text { Selatan }\end{array}$ & $\begin{array}{l}\text { Fragmen wadah gerabah, manik (batu dan } \\
\text { kaca), alat dari kayu (dayung dan bagian dari } \\
\text { perahu) }\end{array}$ & sejarah (?) \\
\hline
\end{tabular}




\begin{tabular}{|c|l|l|l|l|}
\hline No & Nama Situs & \multicolumn{1}{|c|}{ Lokasi } & \multicolumn{1}{|c|}{ Temuan } & Periodesasi \\
\hline 10 & $\begin{array}{l}\text { Penggadingan dan } \\
\text { Tambak Bitin }\end{array}$ & $\begin{array}{l}\text { Kecamatan Daha } \\
\text { Utara, Kabupaten } \\
\text { Hulu Sungai Utara }\end{array}$ & $\begin{array}{l}\text { Fragmen wadah gerabah, genteng tembikar, } \\
\text { batubata, fragmen perhiasan emas, fragmen } \\
\text { keramik asing }\end{array}$ & Sejarah (?) \\
\hline 11 & Candi Agung & $\begin{array}{l}\text { Kabupaten Hulu } \\
\text { Sungai Utara }\end{array}$ & $\begin{array}{l}\text { Struktur bangunan dari batubata, genteng } \\
\text { tembikar, tonggakulin, fragmen wadah gerabah, } \\
\text { manik tanah liat }\end{array}$ & $\begin{array}{l}\text { Abad ke-3 SM (carbon } \\
\text { dating dari sampel arang), } \\
\text { abad ke-8 M (carbon dat- } \\
\text { ing dari kayu ulin }\end{array}$ \\
\hline 12 & Jangkung & $\begin{array}{l}\text { K e c a m a t a n } \\
\text { J a n g k u n g , } \\
\text { K e c a m a t a n } \\
\text { Tabalong }\end{array}$ & $\begin{array}{l}\text { Fragmen wadah gerabah, fragmen keramik } \\
\text { asing }\end{array}$ & Sejarah (?) \\
\hline
\end{tabular}

terlepas dari bagian badannya. Kenyataan itu menunjukkan bahwa kaki berbentuk cincin tersebut ditambahkan setelah bagian badan sudah terbentuk, sehingga hanya menempel secara tidak kuat, sehingga mudah terlepas. Selain bentuk wadah, ditemukan juga gerabah bukan wadah, yaitu manik-manik dan tungku. Manik-manik yang ditemukan memiliki dua macam bentuk, yaitu bulat dempak dan lonjong, dengan ukuran yang berbeda-beda. Fungsi dari manik-manik ini tampaknya berbeda dengan fungsi manik lainnya yang terbuat dari batu atau kaca yang digunakan sebagai perhiasan. Dengan melihat warna dan bentuk manik tanah liat di ketiga situs prasejarah sebenarnya tidak menarik untuk dijadikan perhiasan.

Pola hias yang digunakan pada sebagian besar fragmen gerabah tersebut berupa tera bagor yang memiliki ukuran yang bervariasi, selain itu juga ditemukan tera tikar yang juga memiliki ukuran yang berbeda, ada yang besar dan kecil. Selain itu, hias gores dan tusuk berupa pola geometris juga sudah dikenal meskipun jumlahnya relatif tidak banyak. Gerabah rata-rata memiliki warna yang kusam dan tidak cerah. Penampang lintangnya bahkan banyak berwarna abu-abu, demikian juga dengan sebagian permukaan gerabahnya, baik bagian dalam maupun bagian luar. Keadaan tersebut mencirikan bahwa pembakaran yang dlakukan pada saat proses pembuatannya tidak menggunakan sumber api yang merata. Pembakaran terbukalah yang tampaknya dilakukan oleh pembuat gerabah tersebut dan menggunakan suhu yang rendah serta tidak merata. Penampang lintang yang masih berwarna abu-abu mencirikan bahwa pembakaran dilakukan dibawah suhu 750 derajat celcius. Tampak jelas kondisi gerabah yang sudah aus yang terlihat dari permukaannya yang tidak rata dan memperlihatkan campuran pasir sebagai tempernya. Kondisi tempat terdepositnya fragmen gerabah yang lembab karena dekat dengan sungai juga memperparah kondisi fragmen gerabah yang dibakar dengan suhu rendah tersebut.

Fabric dari fragmen gerabah itu sendiri menunjukkan variasi baik oleh besar kecilnya temper dan pori-pori dari bahan organik penyusun bahan gerabah yang berupa tanah 
liat. Dari hasil pengamatan laboratorium terhadap fragmen gerabah di ketiga situs dapat diketahui bahwa gerabahnya menggunakan temper yang sama yaitu batuan kuarsa, tidak dijumpai adanya limestone di dalamnya. Dari hasil perbandingan yang dilakukan, dapat diketahui adanya beberapa macam fabric yang berbeda dari temuan gerabah di ketiga situs tersebut. Hal itu bisa diasumsikan bahwa gerabah tersebut berasal dari pengrajin yang berbeda. Berdasarkan hasil perbandingan dengan tanah liat di sekitar lokasi situs, menunjukkan bahwa gerabah tersebut dibuat secara lokal. Hal tersebut tampak jelas dari perbandingan fabric penyusun gerabah yang menunjukkan kesamaan. Tampaknya pengrajin pada masa lalu tidak perlu mencampurkan temper secara khusus dalam adonan tanah liat mereka, karena terlihat dengan jelas bahwa tanah liat yang terhampar di sekeliling mereka siap untuk diolah menjadi bentuk gerabah.

Fragmen gerabah selain ditemuan telah bercampur dengan temuan keramik asing pada permukaan tanah, juga ditemukan fragmen gerabah tanpa keramik asing pada lapisan tanah di kedalaman sekitar 1 meter. Sampel arang yang dikirim ke laboratorium ditemukan di antara temuan fragmen gerabah tersebut. Dari hasil pertanggalan terdapat dua kemungkinan yang bisa ditarik sebagai asumsi, yaitu Situs Jambu Hulu memang termasuk dalam pemukiman masa klasik sehingga dapat dikatakan bahwa gerabah di daerah ini tidak banyak mengalami perubahan dari masa sebelum sejarah hingga masa klasik. Begitu juga dengan pemakaian manik gerabah, masih tetap diminati oleh masyarakatnya. Asumsi yang kedua, telah terjadi kesalahan dalam pengambilan sampel arang sehingga didapatkan angka tahun yang jauh lebih muda dari usia situs yang sebenarnya, sehingga diperlukan analisis pertanggalan lagi sebagai data pembanding. Selain itu, permasalahan lain yang mencuat dalam upaya penentuan masa hunian proto sejarah adalah ketiadaan temuan artefak logam. Keberadaan logam di wilayah ini hanya ditandai dengan adanya temuan terak besi, yang antara lain ditemukan di Situs Jambu Hilir dan Jambu Hulu.

Kecenderungan lokasi pemukiman berada di sepanjang aliran sungai, terutama Sungai Nagara dan anak sungainya menyebabkan kesulitan untuk membedakan masa huniannya. Hal tersebut antara lain disebabkan oleh pemakaian hunian secara berkelanjutan dan aktivitas penggalian liar oleh masyarakat, menyebabkan data yang didapatkan sudah bercampur. Keberadaan keramik Cina sebenarnya bisa membantu menentukan masa hunian situs. Akan tetapi, pada kenyataannya rentang waktu yang dihasilkan sangat panjang, dan keberadaan keramik di tempat tersebut kemungkinan tidak semasa dengan usia dinasti yang mengeluarkannya. Pertanggalan absolut yang sudah dilakukan masih belum dapat memberi hasil yang sebenarnya. Hal tersebut dapat terjadi karena beberapa hal, antara lain ada kesalahan dalam mengambil sampel, sampel yang dianalisis hanya ada satu sehingga tidak ada data pembandingnya. Oleh karena itu, keberadaan situs pemukiman di atas perlu dilengkapi dengan pertanggalan absolut dari beberapa sampel, tidak hanya dari sampel kayu atau arang, tetapi juga dari sampel lainnya, misalnya fragmen gerabah dan artefak besi.

Meskipun demikian, dari keberadaan situs-situs pemukiman baik yang sudah maupun yang belum diteliti diketahui bahwa keberadaan situs pemukiman kuna di Daerah Aliran Sungai Barito (masa klasik), terutama 


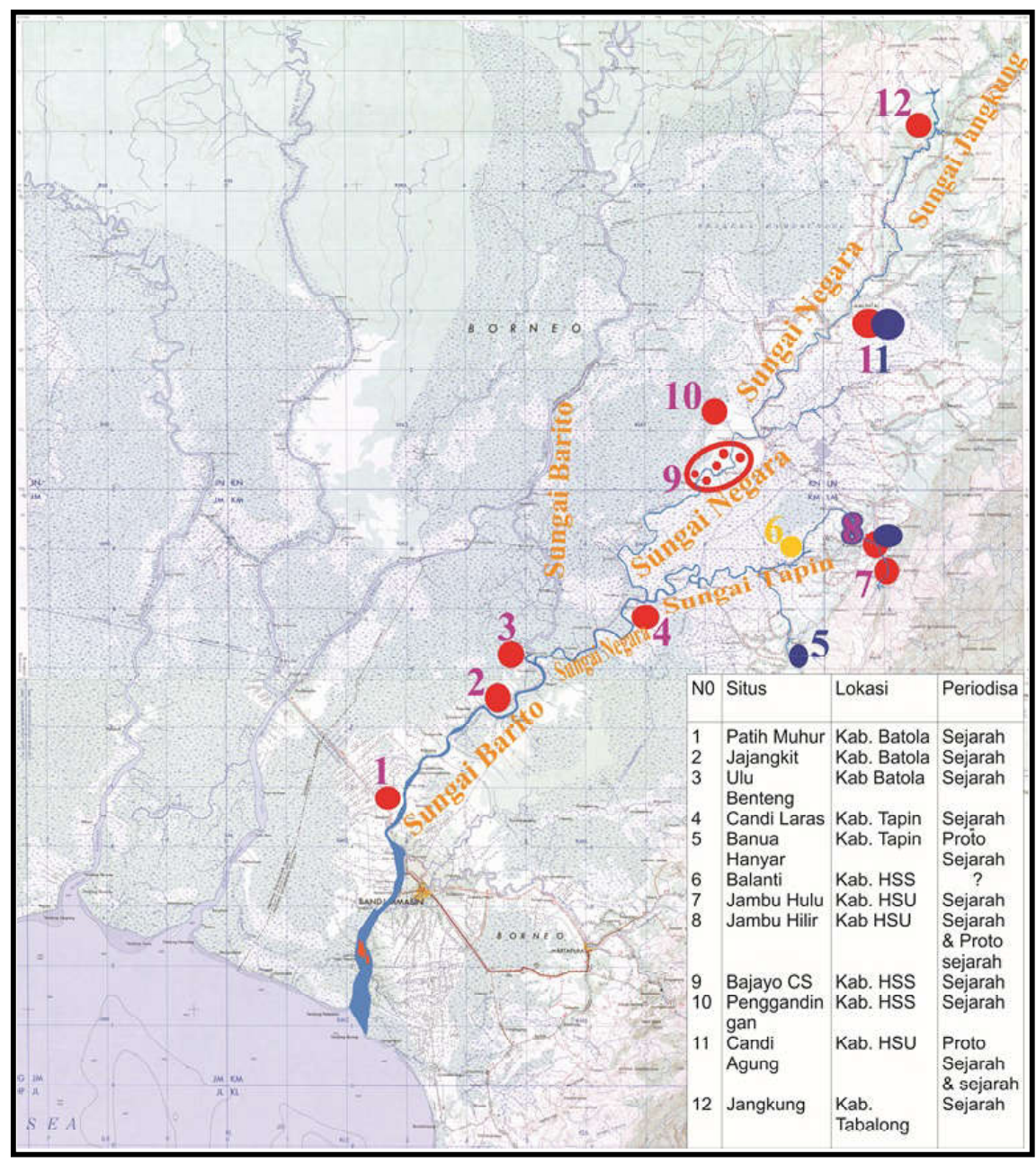

Peta 1. Aliran Sungai Nagara (ditandai dengan garis tebal berwarna biru)

yang berada di sepanjang Sungai Nagara (lihat peta 1) menunjukkan adanya pemukiman yang sangat padat terutama di aliran Sungai Nagara yang mengarah ke hilir, yaitu menuju daerah Margasari yang memiliki Situs Candi Laras dan Pematang Bata. Selanjutnya, ke arah muara Sungai Barito terdapat Situs Patih Muhur. Pemukiman masa klasik tampaknya terpusat di daerah Tumbukan Banyu (Nagara) yang terbagi lagi ke tiga arah yang berbeda, yaitu ke arah Amuntai (Candi Agung), ke arah Barabai, dan ke arah Margasari. Pemukiman kuna yang berada di aliran sungai yang menuju ke Margasari sudah dapat diketahui keberadaannya. Akan tetapi, pemukiman di aliran sungai yang menuju ke Amuntai dan Barabai belum diketahui. Oleh karena itu, perlu dilakukan survei dengan menyusuri aliran sungai dari Tumbukan Banyu ke arah Barabai dan Amuntai. Keberadaan Situs 
Jangkung (dengan temuan fragmen keramik Cina) juga perlu disurvei secara lebih serius, sehingga dapat diketahui sebarannya terutama di aliran Sungai Tabalong dan anak sungainya. Sungai Tabalong ini pada akhirnya juga akan bertemu dengan Sungai Nagara di kota Amuntai.

Demikian juga dengan Sungai Amandit yang membelah kota Kandangan. Beberapa situs pemukiman di aliran Sungai Amandit diketahui juga dimanfaatkan pada masa yang berbeda. Lapisan bawah berasal dari masa yang lebih tua, sedangkan lapisan di permukaan berasal dari masa hunian yang lebih muda, yang diperkuat dengan adanya temuan fragmen keramik asing. Lokasi Situs Jambu Hulu lebih ke arah hulu, mendekati daerah yang lebih tinggi, yaitu Pegunungan Meratus yang merupakan pegunungan karst dengan banyak gua dan ceruk. Dari hasil survei memang ada beberapa ceruk yang potensial untuk dijadikan hunian. Namun demikian, belum ada data yang menghasilkan pertanggalan absolutnya. Apakah hunian di ceruk tersebut lebih tua dibandingkan dengan hunian di aliran Sungai Amandit. Oleh karena itu, gambaran sebaran situs dengan masa huni sebelum masa klasik (ditandai dengan fragmen gerabah tanpa fragmen keramik asing) masih belum menunjukkan pola tertentu.

Oleh karena itu, keberadaan beberapa situs pemukiman kuna, baik dengan temuan fragmen keramik Cina maupun yang tidak, perlu untuk diteliti lebih lanjut, yaitu dengan melakukan survei di sepanjang aliran Sungai Amandit. Selain survei menyusuri sungai tersebut, perlu juga dilakukan ekskavasi guna menentukan pertanggalan absolut pada masing-masing situs. Dengan diketahui masa hunian pada masing-masing aliran sungai, maka pengelompokan terhadap situs yang semasa dapat dilakukan, sehingga peranan masing-masing situs dan hubungan antarsitus dapat diketahui. Selain itu, pola sebaran situs yang cenderung linear mengikuti sungai dapat diketahui dan dapat ditentukan aliran sungai mana yang dihuni terlebih dulu. Perubahan aliran sungai dan perubahan pemukiman dari padat menjadi ditinggalkan juga menjadi data yang penting guna mendukung upaya interpretasi. Adanya perpindahan pemukiman tentunya dipengaruhi oleh banyak faktor.

Guna mengetahui pola sebaran pemukiman dalam satu wilayah tertentu, misalnya pada tempat bertemunya dua atau lebih aliran sungai dapat menggunakan metode analisis keruangan dalam ilmu geografi antara lain dengan menggunakan metode analisa tetangga terdekat (Bintarto dan Hadisumarno 1991, 74-79). Dengan penelitian yang lebih terpadu tersebut diharapkan dapat diketahui sebaran pemukiman masa proto sejarah dan masa klasik terutama di Daerah Aliran Sungai Barito dan anak sungainya yang mengalir di Propinsi Kalimantan Selatan.

\section{Kesimpulan}

Keberadaan situs pemukiman kuna di Propinsi Kalimantan Selatan ini masih belum diteliti secara menyeluruh. Oleh karena itu, perlu dilakukan penelitian yang lebih intensif guna melacak keberadaannya di sejumlah aliran anak Sungai Barito yang potensial, seperti pada daerah persimpangan/tempat bertemunya dua atau lebih aliran sungai. Selain itu, perlu juga dilakukan penyusuran terhadap aliran sungai yang sudah mati, karena kuatnya indikasi pemukiman kuna di tempat-tempat tersebut, yang kemudian ditinggalkan karena beberapa kemungkinan seperti adanya proses pendangkalan atau 
perpindahan aliran sungai, atau alasan teknis lainnya yang menyebabkan lokasi tersebut tidak dapat mendukung lagi kehidupan penghuninya. Pertanggalan absolut sebagai data dukung sangat diperlukan untuk mengetahui masa hunian masing-masing situs, sehingga pola sebarannya dapat diketahui. Hal tersebut akan sangat membantu dalam upaya pengungkapan proses perubahan budaya yang terjadi akibat adanya interaksi dari luar, dan juga untuk dapat memahami cara hidup manusia masa lalu dengan lingkungannya.

\section{Referensi}

Anggraeni dan Sunarningsih. 2008. The Prehistoric settlement at Jambu Hilir, South Kalimantan Province, Indonesia, Ejournal Bulletin of the Indo-Pacific Prehistory Association 28: 120126.

Atmojo, Bambang Sakti Wiku. 1998/1999. Peninjauan di Situs Ulu Benteng, Kecamatan Marabahan Kota, Kabupaten Barito Kuala, Kalimantan Selatan. Laporan Penelitian Arkeologi Banjarmasin. Banjarmasin: Balai Arkeologi Banjarmasin. Belum diterbitkan.

Bintarto R. dan Surastopol Hadisumarmo. 1991. Metode analisa geografi. Jakarta: Lembaga penelitian, pendidikan dan penerangan ekonomi dan sosial.

Gunadi. 2004. Melacak sisa-sisa Kerajaan Banjar di Kawasan Kuin dan Kawasan Kayu Tangi, Kalimantan Selatan. Laporan Penelitian Arkeologi.
Banjarbaru: Balai Arkeologi Banjarmasin. Belum diterbitkan. Harkantiningsih, Naniek dkk. 1999. Metode penelitian arkeologi. Jakarta: Pusat Penelitian Arkeologi Nasional.

Kusmartono, Vida Pervaya Rusianti dan Andi Nuralang. 2001. Kehidupan sosial ekonomi dan perdagangan di daearah pesisir tenggara Kalimantan pada abad ke-19 Masehi. Berita Penelitian Arkeologi 8.

Kusmartono, Vida Pervaya Rusianti dan Harry Widianto. 1997/1998. "Ekskavasi Situs Candi Agung Kabupaten Hulu Sungai Utara Kalimantan Selatan". Berita Penelitian Arkeologi 2.

Nasruddin. 1996/1997. Ekskavasi Situs Jambu Hilir, Kabupaten Hulu Sungai Selatan, Provinsi Kalimantan Selatan. Laporan Penelitian Arkeologi. Balai Arkeologi Banjarmasin. Belum terbit. 
Sunarningsih. 2007. Penelitian ekskavasi permukiman di Nagara, Kabupaten Hulu Sungai Selatan, Kalimantan Selatan. Laporan Penelitian Arkeologi Banjarmasin. Banjarbaru: Balai Arkeologi Banjarmasin. Belum diterbitkan.

Tim Peneliti Arkeologi. 2006. Laporan hasil kajian arkeologi Situs Masjid Keramat, Banua Halat, Kabupaten Tapin, Propinsi Kalimantan Selatan. Kerjasama antara Pemerintah Kabupaten Tapin, Dinas Kebudayaan dan Pariwisata Kabupaten Tapin, dan Balai Arkeologi Banjarmasin, belum terbit.

Triatno, Agus dkk. 1998/1999. Manik-manik koleksi museum negeri Propinsi Kalimantan Selatan Lambung Mangkurat. Banjarbaru: Bagian proyek pembinaan permuseuman Kalimantan Selatan.

Wasita. 2007. Ekskavasi permukiman lahan basah di Situs Gambut, Kabupaten Banjar dan Patih Muhur, Kabupaten Barito Kuala, Kalimantan Selatan. Laporan Penelitian Arkeologi Banjarmasin. Banjarbaru: Balai Arkeologi Banjarmasin. Belum diterbitkan. 